Journal of Patient-Centered

$1-28-2019$

\title{
Defining Patient-Oriented Research for the Average Person (and Potential Research Partner)
}

Dennis J. Baumgardner

Follow this and additional works at: https://aah.org/jpcrr

Part of the Family Medicine Commons, Other Medicine and Health Sciences Commons, Primary Care Commons, Public Health Education and Promotion Commons, and the Translational Medical Research Commons

\section{Recommended Citation}

Baumgardner DJ. Defining patient-oriented research for the average person (and potential research partner). J Patient Cent Res Rev. 2019;6:4-6. doi: 10.17294/2330-0698.1697

Published quarterly by Midwest-based health system Advocate Aurora Health and indexed in PubMed Central, the Journal of Patient-Centered Research and Reviews (JPCRR) is an open access, peer-reviewed medical journal focused on disseminating scholarly works devoted to improving patient-centered care practices, health outcomes, and the patient experience. 


\title{
Defining Patient-Oriented Research for the Average Person (and Potential Research Partner)
}

\author{
Dennis J. Baumgardner, MD | Editor-in-Chief \\ Department of Family Medicine, Aurora UW Medical Group, Aurora Health Care, Milwaukee, WI
}

I $\mathrm{n}$ the lead article of this issue of Journal of PatientCentered Research and Reviews (JPCRR), we find Kaur and Pluye describing their analytical development of an operational definition of patientoriented research (POR) using a modified e-Delphi technique. ${ }^{1}$ The purpose of their study was to adapt a definition of POR that would be adequate and appropriate "to filter and retrieve POR-related publications from bibliographic databases in a reliable manner."

As editor of a medical journal dedicated to improving patient-centered care outcomes as well as the institutional official for a research subject protection program, I fully recognize the importance of their purpose. The authors' resultant definition, which aptly suits its intended use, lays out two conditions that should be met for research to qualify as patient-oriented:

- Condition 1: Patients (including relatives, family caregivers, and the public) are involved as research partners with multidisciplinary or transdisciplinary research team members (including decision/policymakers, patients, and clinicians) along a continuum, (from being consulted to being engaged) in addressing patient priorities or planning/conducting research (eg, formulation of the question; data collection/ analysis; interpretation, diffusion, dissemination, or application of results), or both addressing patient priorities and planning/conducting research.

- Condition 2: Studies are aimed to (a) address outcomes deemed important by patients; (b) have a direct impact

Correspondence: Dennis J. Baumgardner, MD, Aurora Sinai Medical Center, 1020 N. 12th Street, \#4180, Milwaukee, WI 53233 (dennis.baumgardner@aurora.org) on at least one of the following targets: patient health and experiences, health professionals' practice, or health care services and policies; or (c) achieve both objectives $\mathrm{C} 2(\mathrm{a})$ and $\mathrm{C} 2(\mathrm{~b})$.

Such parameters will help researchers identify published works that truly report patient-oriented study outcomes. However, in the words of one anonymous reviewer, "This lengthy definition can fit the need for a standardized search of the literature, but [as a general definition of POR] would be difficult to explain to another person in a regular conversation." Since the very concept of engaging patients in the research process involves working with those generally unfamiliar with scientific terminology, how might we describe POR to the average "person on the street" in more readily understandable language?

As Kaur and Pluye accurately point out, currently there is not a single agreed-upon POR definition worldwide. ${ }^{1}$ The U.S. National Institutes of Health continues to define POR as "research conducted with human subjects (or on material of human origin, such as tissues, specimens, and cognitive phenomena) that requires direct interactions with human subjects."2 In Canada, POR is "a continuum of research that engages patients as partners (and) focusses on patientidentified priorities and improves patient outcomes. This research, conducted by multidisciplinary teams in partnership with relevant stakeholders, aims to apply the knowledge generated to improve healthcare 
systems and practices." ${ }^{3}$ In the United Kingdom, POR is described as "an active partnership between patients and the public and researchers in the research process, rather than the use of people as 'subjects' of research ... for example, involvement in the choice of research topics, assisting in the design, advising on the research project or in carrying out the research." 4

Each of these statements is a bit of a mouthful. Some authors have truncated the concept of POR to simply "research that focuses on an intact person or patient as the unit of observation." ${ }^{5}$ But perhaps this language is too broad and nondescript.

In introducing their topic, Kaur and Pluye condensed the Canadian definition of POR to "a continuum of research that engages patients as partners." This certainly is an appealingly succinct definition, but lacks the examples of "engagement" that the U.K. definition notes. ${ }^{4}$ Two articles previously published in $J P C R R$ and two recent workshop synopses highlight the advantages, challenges, complexities, and nuances regarding patient engagement in research and the inability to measure its effectiveness. ${ }^{6-9}$ As Hahn et al emphasized, patient engagement in research must be genuine, productive, and void of "tokenism."

And to just what does "continuum" refer? Of course, those of us embedded in the edifices know that traditionally it refers to bench-to-bedside translational research. Peter Stacpoole, however, criticized this concept as being a "fundamentally misleading and harmful paradigm for describing patient-oriented [research]." ${ }^{10}$ Contrasting the reality of the iterative, nonlinear, multidimensional process that leads to meaningful discoveries in medicine with the "linear and unidirectional" concept of bench-to-bedside research, Stacpoole emphasized the interdependence of laboratory and patient-oriented research along with the utility of astute bedside hypotheses. ${ }^{10}$ The Canadian Institutes of Health Research also acknowledges the complex, dynamic, and iterative nature of translational research. ${ }^{11}$ Yanos and Ziedonis further emphasized the importance of trained clinician-researchers to bridge the gap between the research and practice communities. ${ }^{12}$

At the turn of this century, Shaywitz et al outlined 5 principles of POR. ${ }^{13}$ Principles 3 and 4 were technical in nature, and the final principle called for a "discrete academic discipline." But the first 2 principles - "the patient is the focus" and "the patient and physician are equal partners and share responsibility"13 remain intriguing as building blocks for a person-onthe-street definition of POR. Serendipitously, they faintly echo Abraham Lincoln's famous description of democracy, "of the people by the people for the people." 14 While I do not envision patients sharing equally in my preparation of microbiologic growth media or performing half of the statistical planning and analysis of a pragmatic clinical trial, I do believe there is value in communicating these fundamental tenets of patient focus and involvement. Many POR experts agree that patient involvement must be meaningful and may include helping set research agendas, input regarding project design and feasibility, feedback on and dissemination of the implications of research results, and sometimes actual involvement in carrying out the project. ${ }^{4,6,8,9,15}$

Freely admitting that I am not myself a POR expert, I wonder if the following could function as a reasonable definition of POR for the average person on the street: research intended to benefit individual patients and that meaningfully partners with patients to plan, conduct, or interpret the study.
Want to

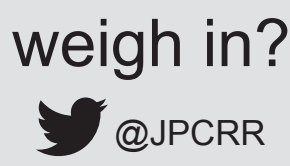

\section{References}

1. Kaur N, Pluye P. Delineating and operationalizing the definition of patient-oriented research: a modified e-Delphi study. J Patient Cent Res Rev. 2019;6:7-16.

2. Strom BL, Norman S, Margolis DJ. Patient-oriented research: definitions and new paradigms. Am J Med. 2000;109:164-5. CrossRef

3. Canadian Institutes of Health Research. Strategy for patientoriented research - patient engagement framework. Page last modified 2014 Jul 2. http://www.cihr-irsc.gc.ca/e/48413. html. Accessed December 31, 2018.

4. INVOLVE. Patient and public involvement. https:// www.invo.org.uk/posttypejargon/patient-and-publicinvolvement/. Accessed December 31, 2018.

5. Concato J. Study design and "evidence" in patient-oriented research. Am J Respir Crit Care Med. 2013;187:1167-72. CrossRef

6. Bombak AE, Hanson HM. A critical discussion of patient engagement in research. J Patient Cent Res Rev. 2017;4:39-41. $\underline{\text { CrossRef }}$

7. Dillon EC, Tuzzio L, Madrid S, Olden H, Greenlee RT. Measuring the impact of patient-engaged research: how a methods workshop identified critical outcomes of research engagement. J Patient Cent Res Rev. 2017;4:237-46. CrossRef 
8. Bishop AC, Elliott MJ, Cassidy C. Moving patient-oriented research forward: thoughts from the next generation of knowledge translation researchers. Res Involv Engagem. 2018;4:23. CrossRef

9. Hahn DL, Hoffmann AE, Felzien M, LeMaster JW, Xu J, Fagnan LJ. Tokenism in patient engagement. Fam Pract. 2017;34:290-5. CrossRef

10. Stacpoole PW. "Bench-to-bedside" - the wrong paradigm for patient-oriented investigation. Acad Med. 2001;76:616. CrossRef

11. Canadian Institutes of Health Research. Guide to knowledge translation planning at CIHR: integrated and end-of-grant approaches. Page last modified 2015 Mar 19. http://www. cihr-irsc.gc.ca/e/45321.html. Accessed December 31, 2018.

12. Yanos PT, Ziedonis DM. The patient-oriented clinicianresearcher: advantages and challenges of being a double agent. Psychiatr Serv. 2006;57:249-53. $\underline{\text { CrossRef }}$
13. Shaywitz DA, Martin JB, Ausiello DA. Patient-oriented research: principles and new approaches to training. Am J Med. 2000;109:136-40. CrossRef

14. Lincoln A. Gettysburg Address. 1863. Draft: Nicolay copy. Transcribed and annotated by the Lincoln Studies Center, Knox College, Galesburg, Illinois. Abraham Lincoln Papers at the Library of Congress, Manuscript Division (Washington, DC: American Memory Project, [2000-02]). http://memory.loc.gov/ ammem/alhtml/malhome.html. Accessed January 2, 2019.

15. Domecq JP, Prutsky G, Elraiyah T, et al. Patient engagement in research: a systematic review. BMC Health Serv Res. 2014;14:89. CrossRef

(C) 2019 Aurora Health Care, Inc. 